\title{
JAMES DOUGLAS WATSON
}

Watson, who died on 21 December 1948, was born in April 1872 . He became a Fellow of the Institute of Actuaries in 1895 and later became a Fellow of the Actuarial Society of America. He began his insurance career with the English and Scottish and rose to the position of Actuary and Secretary under A. G. Scott. He left in 1908 to become the principal officer of the Star until shortly after the I9 $4-18$ war the company was bought by the British Dominions and he became for ten years Vice-Chairman of the combine. He acted as a consulting actuary and much of this work came to him after the death of G. F. Hardy, with whom he was connected as they had married half-sisters. His most important consulting work was done for the Barbados Mutual. Watson was on the Council of the Institute for many years, was Librarian, Hon. Secretary and a Vice-President. He made a valuable contribution to the discussion on Burridge's paper on vaccination, wrote an interesting review of the experience of American companies upon special classes of risks published by the Actuarial Society in I903, and in 1932 he wrote, with J. I. Gopp, a paper on the mortality of insured lives in the West Indies.

That is the bare statement of Watson's actuarial work as it would appear from published records, but to anyone who knew him it conveys no impression of him.

Watson's father was a doctor in Gloucestershire and, thinking it might make easier the education of his two sons and his daughter, he moved to London where he had bought a practice; it was a failure; he tried another part of $I$ ondon with no better result and the financial position became hopeless. J. D., the youngest of the three children, was for a short time at King's College School in the Strand, but he had to leave there at a ridiculously young age and went into a solicitor's office. Both his brother (who afterwards became a F.R.S. and died as the result of the I914-1 8 war) and his sister, who taught, were very intelligent; but though, no doubt, J. D. owed something to those contacts, he owed most to his own brains and exertions. He continued his education at the Regent Street Polytechnic hoping to become a barrister but, when he found that even with the offer of some help from his employer he could not afford the fees, he decided to become an actuary and went as a clerk to the English and Scottish. It must have been a hard struggle, but he obtained his Fellowship and then things went well for him. He had helped himself financially by writing for the insurance press and he did other miscellaneous work, including some dramatic criticisms. On the actuarial side, after becoming a Fellow, he conducted, with W. O. Nash, classes for the final examinations at the institute. He made friends with the bright young actuaries of his own age and they formed together a small dining club which they called by the name of Gallio. It met after the monthly meetings of the Institute. Watson was its Secretary and Treasurer and, in many respects, was the life and soul of the party. Years later, he would smile at his fellow-members when we called him. 'our pious founder', but the description was not far from the truth.

When Watson went to the Star he was appointed to resuscitate an office that had got into a poor state. It had plunged with little skill into foreign business, it had made weak investments, it had declared bonuses too liberally and then had a negligible surplus, the management had been haphazard and, to crown all, there had been an abortive attempt at an amalgamation. Watson worked day and night at the job, and thanks to his wisdom and courage the Star became a profitmaking concern full of life. It was a fine piece of work. He set himself and his staff a high standard; some people even thought he was a hard master, but this 
was never true. He was obliged to eliminate a few of the more inefficient, but the young men who worked with him in those strenuous days still recall his appreciation of their efforts and remember week-ends when Watson and his wife extended charming hospitality to them.

After the profitable sale of the Star, and during the time Watson was on the Board of the new combine, he joined the boards of various financial concerns and made a good deal of money, but much of it vanished when some of the companies were ruined in the Hatry crash. Perhaps, after all, the fortune-making episode could never have been the happiest part of his life and I suspect that Watson got more satisfaction from the consulting actuarial work which he continued to some extent almost to the end of his life.

I owe much to Watson. It began about 50 years ago with an article in the Post Magazine which 1 feel sure he wrote; it gave a course of reading for the final. examinations and enabled me to take them without going to a tutor. Encouragement at the Institute and a most friendly welcome to the Gallio Club, and then, when I went to work under him at the Star, his example, his advice, his generosity and his gaiety gave me a most happy memory shared by many others. Indeed, he had a gift for friendship. 